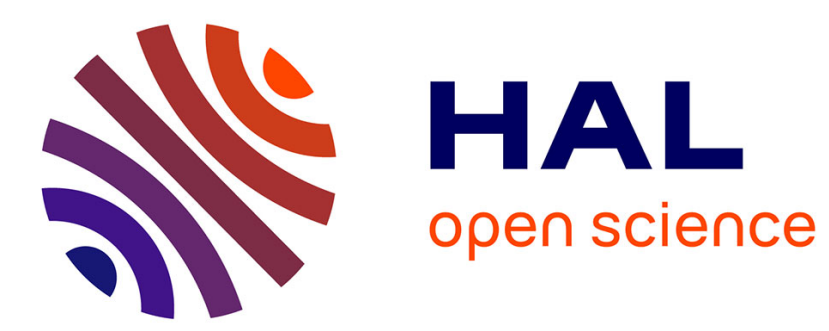

\title{
Colour centres in LiF : Mg crystals
}

A. Watterich, I. Földvári, R. Voszka

\section{To cite this version:}

A. Watterich, I. Földvári, R. Voszka. Colour centres in LiF: Mg crystals. Journal de Physique Colloques, 1980, 41 (C6), pp.C6-159-C6-162. 10.1051/jphyscol:1980641 . jpa-00220079

\section{HAL Id: jpa-00220079 https://hal.science/jpa-00220079}

Submitted on 1 Jan 1980

HAL is a multi-disciplinary open access archive for the deposit and dissemination of scientific research documents, whether they are published or not. The documents may come from teaching and research institutions in France or abroad, or from public or private research centers.
L'archive ouverte pluridisciplinaire HAL, est destinée au dépôt et à la diffusion de documents scientifiques de niveau recherche, publiés ou non, émanant des établissements d'enseignement et de recherche français ou étrangers, des laboratoires publics ou privés. 


\title{
Colour centres in LiF : Mg crystals
}

\author{
A. Watterich, I. Földvári and R. Voszka \\ Research Laboratory for Crystal Physics, Hungarian Academy of Sciences, \\ Budapest XI, Budaörsi ùt 45 , Hungary
}

\begin{abstract}
Résumé. - Deux types de centres $\mathrm{H}^{0}$ et un centre $\mathrm{H}^{-}$ont été trouvés par RPE et absorption UV dans le vide, dans des cristaux de $\mathrm{LiF}: \mathrm{Mg}$ irradiés aux rayons $\mathrm{X}$. Les centres appelés $Z_{3}$ et $Z_{2}$ dans $\mathrm{LiF}: \mathrm{Mg}$ ne peuvent pas être identifiés à aucun centre $Z$, ils sont plutôt en connexion avec l'impureté $O H$.
\end{abstract}

Abstract. - Two types of $\mathrm{H}^{0}$ centres and one $\mathrm{H}^{-}$centre were found by ESR and vacuum UV measurements in $\mathrm{X}$-irradiated $\mathrm{LiF}: \mathrm{Mg}$. The so called $\mathrm{Z}_{3}$ and $\mathrm{Z}_{2}$ centres in $\mathrm{LiF}: \mathrm{Mg}$ are not identical with any $\mathrm{Z}$ centre and are rather connected to the $\mathrm{OH}$ impurity.

1. Introduction. - A thorough knowledge of colour centres in $\mathrm{LiF}$ : $\mathrm{Mg}$ is necessary for understanding the TL mechanism in this thermoluminescent dosimetry material. Some authors emphasize the role of $\mathrm{OH}$ and $O$ [1-4], but others are of the opinion that most important in the TL mechanism are $Z$ centres [5-7].

The optical absorption bands at 310 and $225 \mathrm{~nm}$ were previously identified as $Z_{2}$ and $Z_{3}$ bands, respectively, since they follow a Mollwo-Ivey type relationship $[5,7]$ and since the second is produced from the first by thermoionization [6] or photoionization [7].

In $\mathrm{X}$-irradiated LiF : Yb, we have shown the presence of monovalent $\mathrm{Yb}$ (unpublished ESR result) though $\mathrm{Yb}$ is a typical dopant forming $\mathrm{Z}$ centres in $\mathrm{KCl}$ [8]. But $\mathrm{Mg}$ ions form ordinary $\mathrm{Z}$ centres neither in $\mathrm{NaCl}$ nor in $\mathrm{KCl}[9,10]$. Therefore it was necessary to re-examine the assumptions made about $\mathrm{Z}$ centres in $\mathrm{LiF}: \mathrm{Mg}$.

2. Experimental. - Merck suprapure LiF was doped by $3 \times 10^{-4}$ mole fraction of $\mathrm{MgF}_{2}$. Single crystals were grown by a vertical zone melting technique in inert atmosphere. $\mathrm{LiF}:(\mathrm{Mg}, \mathrm{OH})$ crystals were grown in air. The annealing treatments were made in air. The X-irradiation was carried out by a THX250 deep-therapy appatus operated at $200 \mathrm{kV}, 20 \mathrm{~mA}$ and $\sim 9000 \mathrm{R} / \mathrm{min}$. For ESR and vacuum UV measurements an ERS-XQ type spectrometer and a Beaudouin MVR-100 type monochromator were used, respectively.

3. Results and discussion. - The ESR spectrum of an as cleaved $\mathrm{LiF}: \mathrm{Mg}$ crystal $\mathrm{X}$-irradiated for 3 hours is very complex (Fig. 1a). Annealing this sample the intensities of some lines decrease. For annealing temperatures between 130 and $220^{\circ} \mathrm{C}$ a doublet appears (Fig. 1a). The ESR parameters of this doublet are :

$$
A=(47.5 \pm 2) \mathrm{mT}, \quad g=2.007 \pm 0.001 \text {. }
$$

This centre may be identified as a $\mathrm{H}$ atom, since the proton HF constant in a free $\mathrm{H}$ atom is $50.7 \mathrm{mT}$ and the $\mathrm{U}_{2}$ and $\mathrm{U}_{3}$ centres ( $\mathrm{H}^{0}$ in various positions) possess similar HF constants in alkali halides [11-13].

The presence of $\mathrm{H}^{0}$ indicates with great probability that the $\mathrm{LiF}: \mathrm{Mg}$ contains $\mathrm{OH}$ impurities.

Rising the annealing temperature to $440^{\circ} \mathrm{C}$ (Fig. $1 b$ ) the ESR spectrum consisting of lines 2, 4 and 6 becomes dominant. Measuring the same sample at lower than room temperature, one can easily see that this spectrum is still complex (Fig. 1c). Therefore the ESR parameters of the spectrum measured at RT (lines 2, 4 and 6) can be given only tentatively (Table I) using the spectra obtained for various orientations of the magnetic field relative to the crystal axes (Fig. 1c). After annealing at $500^{\circ} \mathrm{C}$ the ESR spectrum disappears.

Figure 2 shows the vaccum UV absorption spectrum of a non-irradiated $\mathrm{LiF}: \mathrm{Mg}$. The band at $\sim 124 \mathrm{~nm}$ may be due to $\mathrm{OH}$ impurities. The spectrum of the crystal X-irradiated for 1 hour is very complex. After annealing at $400{ }^{\circ} \mathrm{C}$ the spectrum consists of the bands at $127,222 \mathrm{~nm}$ (hypothetic $Z_{3}$ band) and of absorption in the $150-190 \mathrm{~nm}$ range (Fig. 2).

A band at $127.3 \mathrm{~nm}$ was identified in $\mathrm{LiF}$ as a $\mathrm{H}^{-}$ ion [14], one can assume that the band at $127 \mathrm{~nm}$ is the same.

Repeating the measurements in LiF crystals containing various amounts of $\mathrm{Mg}$ and $\mathrm{OH}$ one can see that the absorption band at $222 \mathrm{~nm}$ and the RT ESR spectrum (lines 2, 4 and 6) are correlated. Thus the latter ESR spectrum is due to the so called $Z_{3}$ centre.

Paramagnetic centres of Z-type should have ESR 


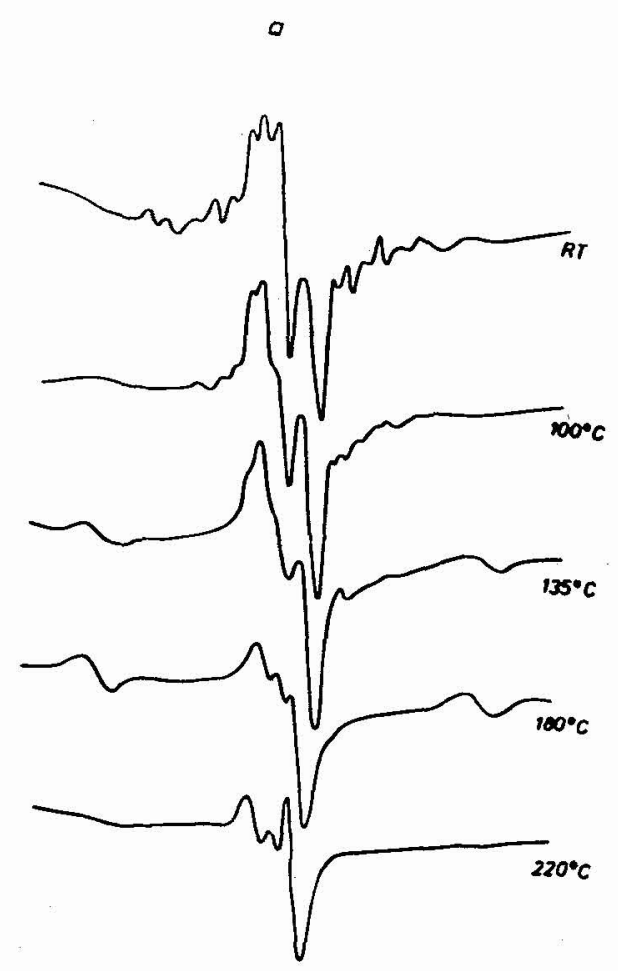

Fig. 1. - ESR spectra of as cleaved $\mathrm{LiF}: \mathrm{Mg} \mathrm{X}$-irradiated for 3 hours. $a, b$ ) After annealing the same crystal at the temperatures indicated, $H / /[100]$, measured at RT; $c$ ) After annealing at

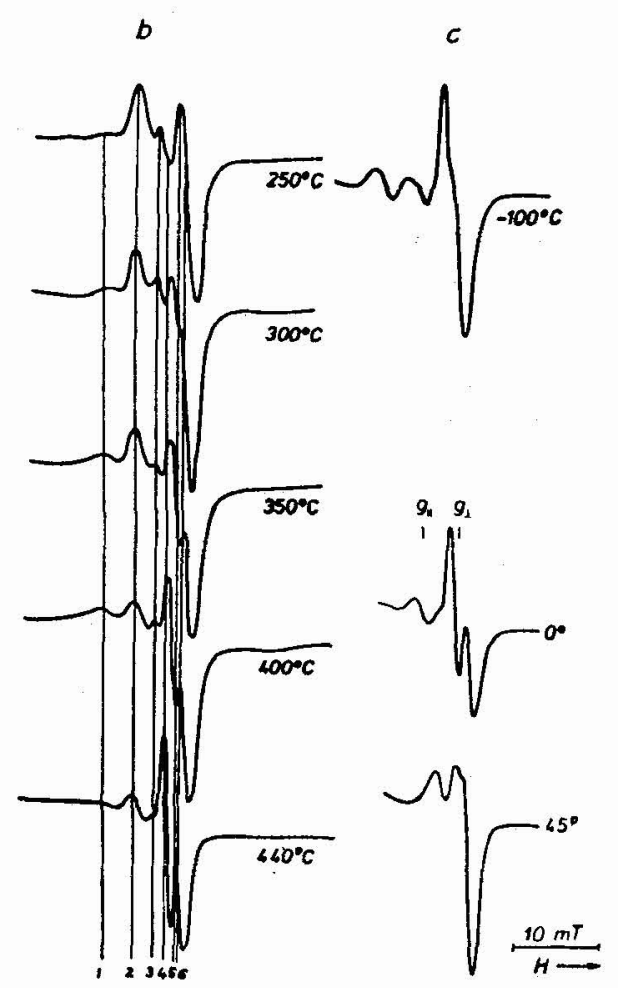

$440{ }^{\circ} \mathrm{C}, H / /[100]$, measured at $-100^{\circ} \mathrm{C}$ (upper spectrum), the same as before but measured at RT (central spectrum), the same as before but $H / /[110]$, measured at RT (lowest spectrum).

Table I. - Values of various components of the HF-, g-tensor and of the peak-to-peak line widths of the ESR spectra.

\begin{tabular}{|c|c|c|c|c|c|}
\hline Centre & $\begin{array}{c}\text { Host } \\
\text { material }\end{array}$ & $|A|(\mathrm{mT})$ & $g$ & $\Delta H(\mathrm{mT})$ & Refs. \\
\hline$F$ & $\begin{array}{l}\mathrm{LiF} \\
\mathrm{KCl}\end{array}$ & - & $\begin{array}{l}2.000 \\
1.996\end{array}$ & $\begin{array}{l}15 \\
4.6\end{array}$ & [15] \\
\hline$Z_{3}$ & $\mathrm{KCl}$ & - & 1.996 & 3.9 & [16] \\
\hline$\cdot \mathrm{OH}$ & & $\begin{array}{l}A_{x}=2.6 \\
A_{y}=4.4 \\
A_{z}=0\end{array}$ & $\begin{array}{l}g_{\perp}=2.007 \\
g_{\|}=2.06\end{array}$ & & [17] \\
\hline \multirow[t]{2}{*}{$\mathrm{FOH}^{-}$} & $\begin{array}{l}\text { aqueous } \\
\text { KF }\end{array}$ & $\begin{array}{l}A_{x}(\mathrm{H})=2.5 \\
A_{y}(\mathrm{H})=4.0 \\
A_{z}(\mathrm{H}) \sim 0\end{array}$ & $\begin{array}{l}g_{\perp}=2.009 \\
g_{\|}=2.1\end{array}$ & & [17] \\
\hline & $\mathrm{LiF}: \mathrm{Mg}$ & $\begin{aligned} A_{\perp} & \sim 2.0 \\
A_{\|} & \sim 0\end{aligned}$ & $\begin{array}{l}g_{\perp} \sim 2.006 \\
g_{\|} \sim 2.029\end{array}$ & $\begin{array}{l}\sim 1.3 \\
\sim 2.6\end{array}$ & $\begin{array}{c}\text { present } \\
\text { work }\end{array}$ \\
\hline
\end{tabular}

spectra similar to that of the $F$ centre. This is really the case for the $\mathrm{Z}_{3}$ centre in $\mathrm{KCl}$ (Table I). Comparing the ESR parameters of the $F$ centre in $\mathrm{LiF}$ and the ESR spectrum in question, the differences are obvious. From these and the similarities to $\mathrm{OH}$ and $\mathrm{FOH}^{-}$ radicals (Table $I$ ) one may conclude that this centre is not of Z-type but probably one connected to the $\mathrm{OH}$ impurity.

Further on one has to assume, that the centre from which the so called $Z_{3}$ centre can be created by ionization, is no $Z_{2}$ centre, either.

In $\mathrm{LiF}(\mathrm{Mg}, \mathrm{OH})$ annealed at $600^{\circ} \mathrm{C}$ and $\mathrm{X}$-irradiated for 3 hours a new complex ESR spectrum is produced (Fig. 3). (The same spectrum can probably be produced in annealed $\mathrm{LiF}: \mathrm{Mg}$, but its concentration is very low.) The central part of the spectrum is again the superposition of several spectra, therefore only the wing lines could be used for analysis. The 


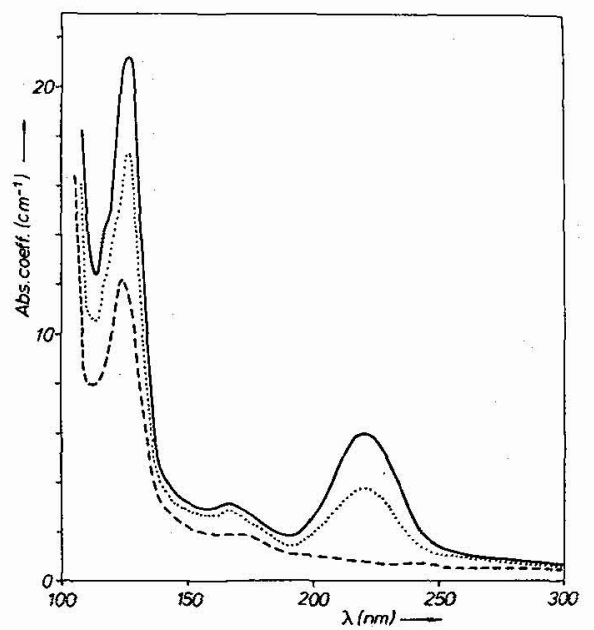

Fig. 2. - Vacuum UV spectra measured at $\mathrm{RT}$ of $\mathrm{LiF}: \mathrm{Mg}$ (- - ), after $\mathrm{X}$-irradiation for 1 hour and after annealing at various temperatures : $400^{\circ} \mathrm{C}(-), 450^{\circ} \mathrm{C}(\ldots)$ and $500^{\circ} \mathrm{C}$ $(--\cdots)$.

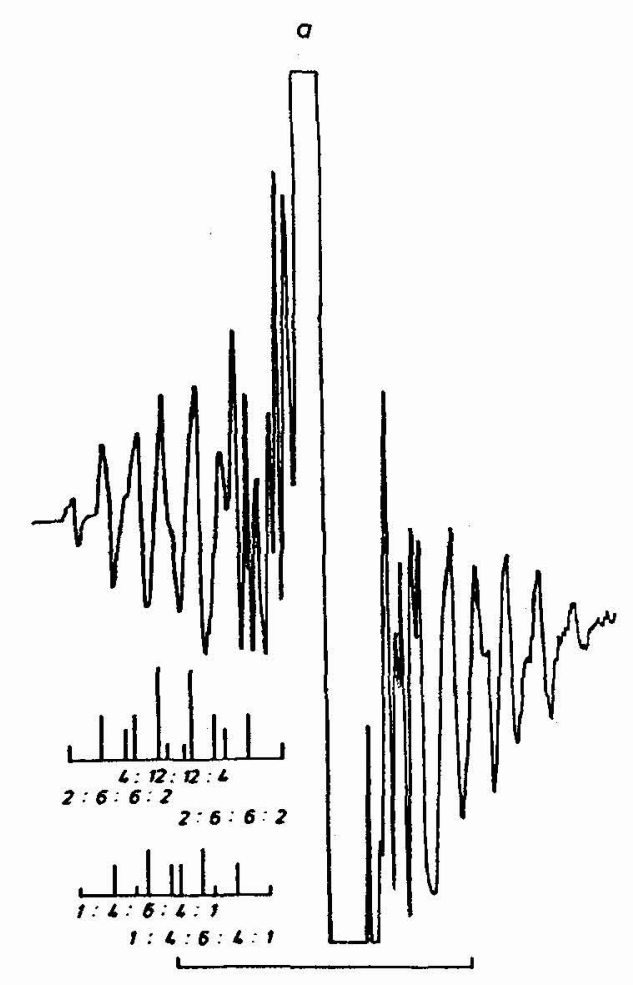

Fig. 3. - ESR spectra measured at RT of annealed (at $600{ }^{\circ} \mathrm{C}$ ) $\mathrm{LiF}:(\mathrm{Mg}, \mathrm{OH}) \mathrm{X}$-irradiated for 3 hours. a) $H / /[100]$; b) $H / /$ [110]. The expected spectra were calculated assuming a $\mathrm{H}^{0}$ at a cation site surrounded by $5 \mathrm{~F}^{-}$ions. The largest splitting is due to splittings and intensity ratios of the HF and SHF lines could be interpreted as due to a $\mathrm{H}^{0}$ occupying a cation site surrounded by $5 \mathrm{~F}^{-}$ions and probably one anion vacancy. The ESR parameters can be given qualitatively because of the superpositions :

$$
\begin{gathered}
A(\mathrm{H}) \sim 55.6 \mathrm{mT}, \quad\left|A_{\|}(\mathrm{F})\right| \sim 12 \mathrm{mT}, \\
\left|A_{\perp}(\mathrm{F})\right| \sim 7.4 \mathrm{mT} \quad \text { and } g \sim 2.003 .
\end{gathered}
$$

4. Conclusion. - On the basis of the results presented, one can say that the $\mathrm{LiF}: \mathrm{Mg}$ crystals grown in inert atmosphere are not $\mathrm{OH}$-free. X-irradiation results in various centres $\left(\mathrm{H}^{0}, \mathrm{H}^{-}\right.$and $\left.\mathrm{OH}\right)$ like in other alkali halides containing $\mathrm{OH}^{-}$. These centres must be taken into account in the interpretation of the TL mechanism.

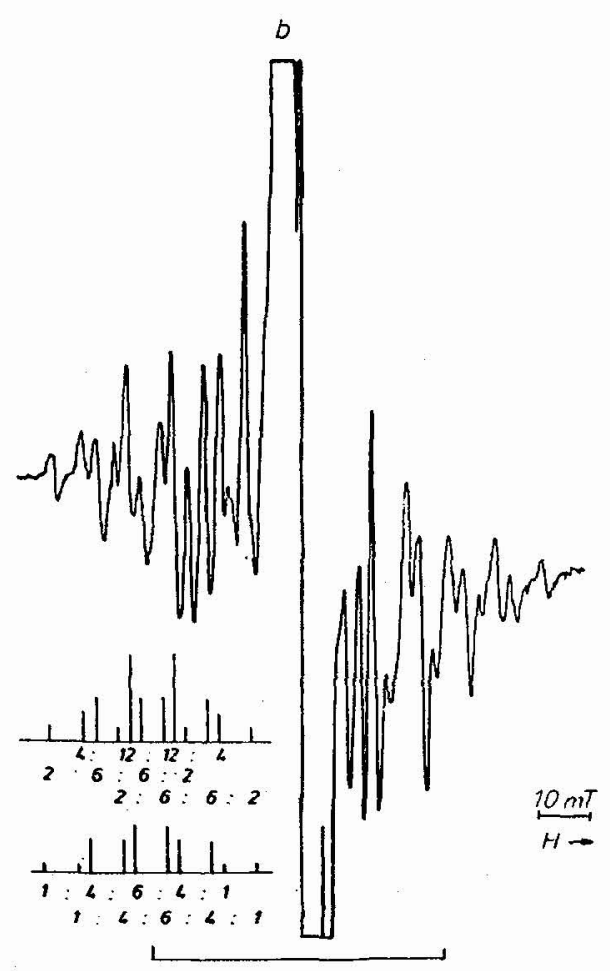

the HF interaction with the proton in both spectra. Two different SHF spectra due to the interactions with $\mathrm{F}$ nuclei are superimposed in both orientations in accordance with the two possible different positions of the $\mathrm{F}^{-}$vacancy.

\section{DISCUSSION}

Question. - W. A. Sibley.

Sometime ago Bill Johnson and John Nadean showed a direct relationship between the concen- tration of $\mathrm{Ca}^{2+}$ and the $\mathrm{OH}$ concentration in $\mathrm{NaCl}$ as measured by infrared absorption $\left(\mathrm{Ca}(\mathrm{OH})_{2}\right)$. Did you measure the infrared absorption for your crystals? 


\section{Reply. - A. WaTteRICH.}

T. G. Stoebe showed the IR absorption spectrum of $\mathrm{Mg}^{2+}-\mathrm{OH}^{-}$complexes in LiF. We checked our $\mathrm{LiF}: \mathrm{Mg}$ crystal and found the same line at $2.8 \mu$.

\section{Question. - S. P. MoRato.}

Did you correlate your ESR data with thermally stimulated luminescence data?

\section{Reply. - A. WATTERICH.}

We checked our LiF : Mg crystal by thermoluminescence measurement and we got quite the same glow peaks as usual, but we have measured TL at RT as well.

\section{Question. - R. J. Friauf.}

Some years ago a student of mine (F. Pilcher) made optical absorption measurements on $\mathrm{LiF}: \mathrm{Mg}$ crystals colored at high temperature (about $200^{\circ} \mathrm{C}$ ) by neutron irradiation. We observed a definite relationship between the height of the $222 \mathrm{~nm}$ band and the amount of magnesium present. There may well have been some $\mathrm{OH}^{-}$present, but we did feel that the $222 \mathrm{~nm}$ band was definitely related to the presence of $\mathrm{Mg}$.

\section{Reply. - A. WATTERICh.}

We don't argue against the Mg content of the colour centre giving absorption band at $222 \mathrm{~nm}$.

\section{References}

[1] Crittend, G. C., Townsend, P. D., Gilkes, J. and WintersGILl, M. C., J. Phys. D 7 (1974) 2410.

[2] Stoebe, T. G. and Watanabe, S., Phys. Status Solidi (a) 29 (1975) 11.

[3] Wintersgill, M. C., Townsend, P. D. and Cusso-Perez, F., J. Phys. 7 (1977) 123.

[4] Wintersgill, M. C. and Townsend, P. D., Phys. Status Solidi (a) 47 (1978) K67.

[5] Mort, J., Phys. Lett. 21 (1966) 124.

[6] Niń, R. and Kos, H.-J., Phys. Status Solidi (a) 35 (1976) 121.

[7] Menta, S, K., Merklin, J. F. and Donnert, H. J., Phys. Status Solidi (a) 44 (1977) 679.

[8] UмBaCh, K. H., Kenntner, G. and Paus, H. J., J. Phys. C 9 (1973) 107.

[9] Voszka, R. and Watterich, A., Phys. Status Solidi (b) 55 (1973) 787.
[10] Watterich, A. and Raksanyi, K., Phys. Status Solidi (b) 80 (1977) K 105.

[11] Delbecq, C. J., Smaller, B. and Yuster, P. H., Phys. Rev. 104 (1956) 599.

[12] Hayes, W. and Hodby, J. W., Proc. R. Soc. London A 294 (1966) 359.

[13] Spaeth, J. M. and Sturm, M., Phys. Status Solidi 42 (1970) 739.

[14] Beaumont, J. H., Bordas, J., Bourdillon, A. J. and Hayns, M. R., J. Phys. C 7 L (1974) 349.

[15] Seidel, H. and Worf, H. C., Phys. Status Solidi 11 (1965) 3.

[16] Ohrura, H., Phys. Rev. 136 A (1964) 446.

[17] Ginns, I. S. and Symons, M. C. R., J. Chem. Soc. Dalton Trans. (1972) 143. 